\title{
Influence of forest site on total nonstructural carbohydrate levels of pinegrass, elk sedge, and snowberry
}

\author{
JANICE K. KRUEGER AND DONALD J. BEDUNAH
}

\section{Abstract}

Seasonal trends in total nonstruetural carbohydrates (TNC) were studied in pinezrass (Calamagrostis rubescens Buckl.), elk sedge (Carex geyeri Boott), and snowberry (Symphoricarpos albus (L.) Blake) in western Montana in 1983 and 1984. Plants were collected from 4 forest sites at approximate 2-week intervals throughout the growing season. The sites were a clearcut and forested area in $\mathbf{2}$ different habitat types. Total nonstructrual carbohydrates were determined using an enzyme digestion technique and acid hydrolysis. Total nonstructural carbohydrates in pinegrass rhizomes exhibited a U-shaped curve with reduced levels during growth initiation in the spring and increased levels after growth cessation in late summer. Snowberry root crown TNC exhibited a V-shaped curve with rapid drawdown caused by spring growth followed by rapid replenishment of TNC levels. Elk sedge, an evergreen, did not have a stage of development which resulted in large fluctuations in TNC content of roots or root crowns. In general, TNC levels in elk sedge roots and root crowns and snowberry root crowns were greater on forested sites than clearcuts while the opposite was found in pinegrass rhizomes. Phenological development of plants growing under the forest canopy was delayed by 2 to 3 weeks compared to plants growing in the clearcuts. The influence of clipping pinezrass and elk sedge to a 5-cm or 10-cm stubble height in late May and late June was also studied. Elk sedge TNC levels were least affected when plants were clipped to a 10-cm height in late May and most affected when clipped to a 5-cm height in either May or June. Pinezrass rhizome TNC levels were lower than controls 2 weeks after clipping to $5-\mathrm{cm}$ stubble heights in late May and late June, but after 4 weeks TNC levels of 5-cm clipped plants were not different from controls. Clipping to a 10-cm stubble height in late May did not cause a reduction in TNC levels. The $10-\mathrm{cm}$ clipping treatment reduced pinegrass rhizome TNC levels compared to the control 2 weeks after clipping in late June. The replenishment of TNC reserves of elk sedge and pinegrass to moderate foliage removal during the spring suggests that these species may be moderately grazed in early spring when they are more palatable to livestock.

Key Words: Calamagrostis rubescens, Carex geyert, Symphortcarpos albus, transitory range, forest grazing

Forested areas in western Montana provide valuable forage for livestock and wildlife. Production of forage beneath a forest canopy varies among habitat types and as a result of the density and nature of the tree cover (Willard et al. 1983). Clearcutting and other logging methods create transitory range which may provide large quantities of forage for livestock. Pinegrass (Calamagrostis rubescens Buckl.), elk sedge (Carex geyeri Boott), and snowberry (Symphoricarpos albus (L.) Blake) are the dominant forage plants associated with several forest habitat types of the northwest United States and Canada. Pinegrass is a slender, tufted grass that is considered fair forage for cattle and elk (Stubbendieck et al. 1982). Reproduction is by rhizomes or by seed in open areas. Elk sedge is a caespitose, dry land sedge which reproduces by seeds and rhizomes and is considered good forage for cattle and elk (Stubben-

\footnotetext{
Authors are graduate research assistant and associate professor, School of Forestry, University of Montana, Missoula 59812. Krueger is currently range conservationist, U.S. Forest Service, Sula Ranger Station, Sula, Mont. 59871.

This research was supported by McIntre-Stennis Grant No. MONZ 8305 Manuscript accepted 14 October 1987
}

dieck et al. 1982). Snowberry is a rhizomatous shrub used as browse by cattle, deer, and elk.

Management of forested range is difficult because of the complex of environments which influence forage plant physiology. Also, when logging practices remove the forest overstory, there are changes in precipitation and radiation reaching the soil surface, which influence available soil water, soil temperatures, and forage plant growth and phenology. Trlica (1977) stated there was a need for studies to establish relationships among carbohydrate reserve cycles, growth, and phenological stage of development, and to determine at what phenological stages of development plants are most detrimentally affected by defoliation. Therefore, the primary objective of this study was to describe the seasonal carbohydrate cycles of pinegrass, elk sedge, and snowberry as affected by forest habitat type, canopy cover, and plant phenology. A secondary objective was to determine the influence of clipping on TNC levels of pinegrass and elk sedge.

\section{Study Area}

The study sites were located $56 \mathrm{~km}$ northeast of Missoula, Montana on the Lubrecht Experimental Forest. The major vegetation types on the forest are second-growth stands of Douglas-fir (Pseudotsuga menziesii (Mirbel) Franco) or ponderosa pine (Pinus ponderosa Laws) with understories consisting primarily of pinegrass, elk sedge, snowberry, and dwarf huckleberry (Vaccinium caespitosum Michx.). Annual average temperature on the forest is $4.0^{\circ} \mathrm{C}$ and yearly precipitation averages $44.3 \mathrm{~cm}$ (Steele 1981). January is the coldest month, averaging $-8.4^{\circ} \mathrm{C}$, while July's $16.8^{\circ} \mathrm{C}$ average is the warmest. Precipitation is greatest in January and June averaging $6.0 \mathrm{~cm}$ and $6.3 \mathrm{~cm}$, respectively. Summer precipitation is low, averaging $2.4 \mathrm{~cm}$ in July and $2.7 \mathrm{~cm}$ in August.

Four sampling sites representing 2 habitat types each with a clearcut and undisturbed forest area were selected in the spring of 1983. The 4 sampling sites were: (1) a Douglas-fir/snowberry habitat type with a dominant overstory of ponderosa pine, canopy cover averaging $50 \%$, elevation of $1,230 \mathrm{~m}, 10 \%$ slope and southern exposure; (2) a clearcut adjacent to Site 1 with the same elevation, slope and aspect; (3) a Douglas-fir/dwarf huckleberry habitat type with an overstory of Douglas-fir and western larch (Larix occidentalis Nutt.), canopy cover averaging $60 \%$, elevation of $1,260 \mathrm{~m}$, slope less than 5\%, and northwest exposure; and (4) a clearcut adjacent to Site 3 with the same elevation, slope and aspect. The soil of the ponderosa pine forest and clearcut was a Shooflin silt loam, a member of the very fine, montmorillonitic, Typic Eutroboralfs. The soil of the Douglas-fir forest and clearcut was a Crow silt loam, a member of the fine mixed, Typic Eutroboralfs. The 4 sites will be referred to as the ponderosa pine forest, ponderosa pine clearcut, the Douglas-fir forest, and the Douglas-fir clearcut.

\section{Methods}

\section{Sample Collection and TNC Analysis}

Elk sedge, pinegrass, and snowberry plants were collected at approximate 2-week intervals from 13 April through 22 October in 1983 and from 19 March through 22 August in 1984. Early summer dormancy occurred in 1984 because of dry conditions and plant collections were terminated. A late fall collection was made on 30 


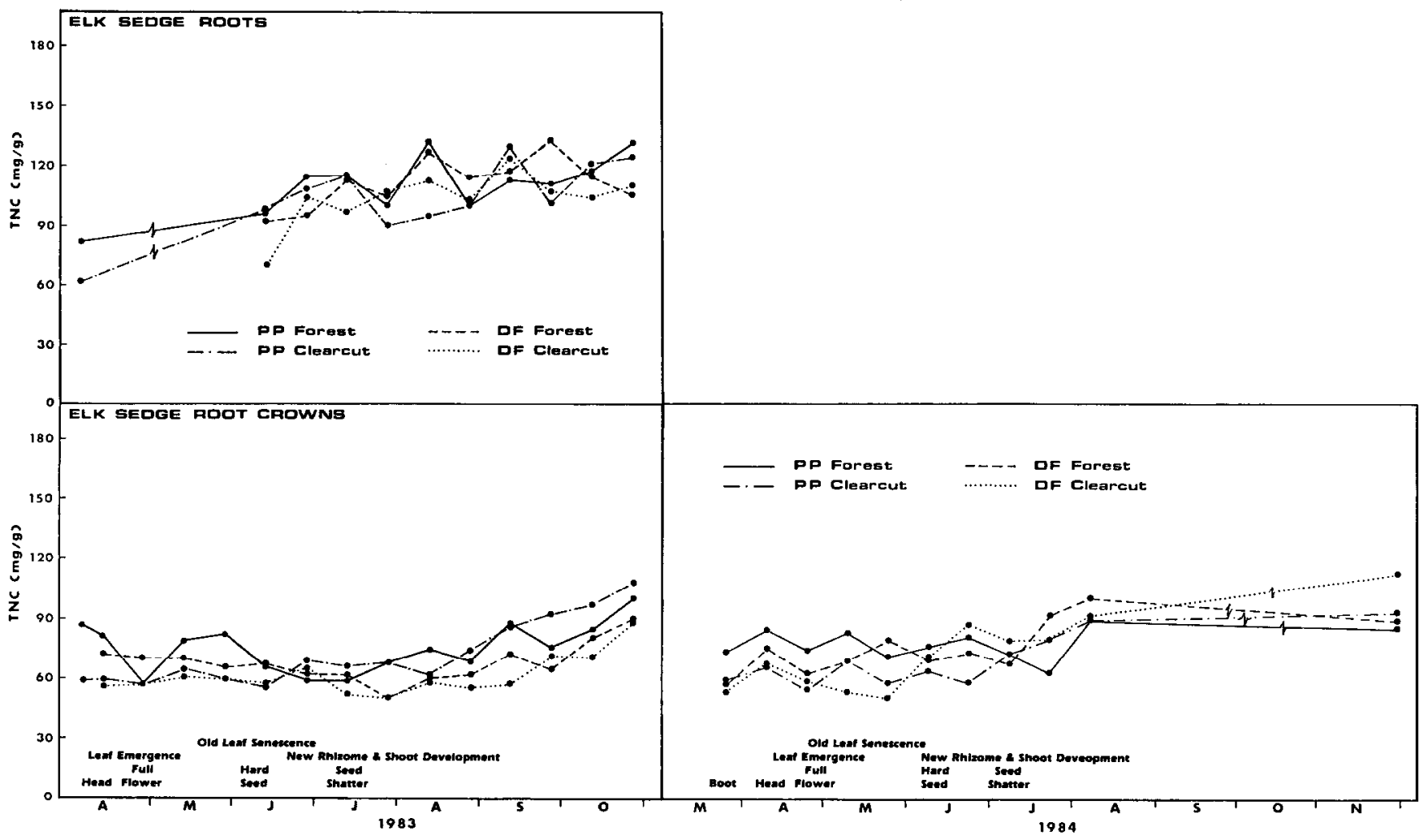

F1.5. The influence of site and date on total nonstructural carbohydrates ( $\mathrm{mg} / \mathrm{g}$ ) in elk sedge roots and root crowns in 1983 and 1984 . Phenological stages of development are also included.

November 1984. Five representative plants of each species were collected on each site and date. Sampling began at dawn when air temperatures were low to minimize loss of total nonstructural carbohydrates (TNC) from respiration and to avoid diurnal variation. Stout et al. (1983) reported that TNC levels in combined rhizomes and roots of pinegrass were higher than TNC in root crowns, and the TNC seasonal pattern of crowns was quite erratic. We collected rhizomes to a depth of $20 \mathrm{~cm}$ removing all fibrous roots to eliminate their interference. Studies involving the TNC cycles of Nebraska sedge (Carex nebraskensis Dewey) (Steele et al. 1984) and C. lacustris Willd. (Roseff and Bernard 1979) stress the importance of the TNC content of rhizomes to these species. In elk sedge, rhizomes were often absent or when present usually no more than $1 \mathrm{~cm}$ in length; thus, rhizomes constituted only a small portion of the underground tissue. Therefore, we collected all roots to a depth of $20 \mathrm{~cm}$ for a belowground sample and a $2-\mathrm{cm}$ to $3-\mathrm{cm}$ section of root crown for an aboveground sample. Crown material of snowberry was defined as the swollen base of the plant located at or below ground level. Crown samples of snowberry included 3-cm of rhizomes from the crown. All samples were immediately placed on dry ice to slow respiration during transport to the lab. The samples were washed with cold water to remove soil particles, dried at $105^{\circ} \mathrm{C}$ for 10 minutes to stop enzymatic action, then dried at $65^{\circ}$ $\mathrm{C}$ for 7 days. The dried material was ground in a Wiley mill to pass a 60-mesh screen, then stored in air-tight containers. The phenological stage of development was noted for each plant sampled. Soil temperature was measured at a 15-cm depth on each site and collection date and also at a $30-\mathrm{cm}$ depth on the ponderosa pine sites. Gravimetric soil water (\%) was measured using soil cores extracted to $15-\mathrm{cm}$ depth for all sites and all collection dates and also from $15-\mathrm{cm}$ to $30-\mathrm{cm}$ depth on the ponderosa pine sites (Hillel 1971).

Total nonstructural carbohydrate levels were measured in elk sedge and snowberry using an enzyme digestion technique developed by daSilveira et al. (1978). Pinegrass, which is high in fructosans, was treated with $0.4 \mathrm{~N} \mathrm{H}_{2} \mathrm{SO}_{4}$ acid for 20 min after enzyme digestion (Smith et al. 1964). No differences were found in the TNC levels of elk sedge or snowberry tissues before and after acid hydrolysis. TNC concentration in the plant tissue was read spectrophotometrically and expressed on a $\mathrm{mg} / \mathrm{g}$ dry weight basis (daSilveira et al. 1978).

\section{Clipping Treatments}

Moderate and severe clipping treatments were applied to elk sedge and pinegrass on 24 May and again on 23 June 1984 to test for differences in response to early and late herbage removal on the 4 sites. Plants were clipped to a $10-\mathrm{cm}$ stubble height for the moderate treatment or a 5-cm stubble height for a severe treatment (Stout et al. 1980). Four plants of each species of the clipped plants were collected 2 and 4 weeks following clipping to measure the amount of TNC change with time. The amount or regrowth was determined by measuring the length of leaves from the point of clipping at the 2-and 4-week intervals.

\section{Statistical Analysis}

The seasonal TNC cycles were compared using a completely randomized design in a factorial arrangement. The factors were site and date with 5 randomly chosen plants per species on each date as replications. We did not replicate the sites, therefore our conclusions about the TNC trends apply only to these sites. The 1983 pinegrass collections were not statistically analyzed because of difficulties in the laboratory. The influence of clipping treatments was determined using a completely randomized design with a factorial arrangement. The factors were treatment (clipping intensity), date, and site. The clipping treatments were replicated (4 replications/treatment) by applying 1 of 3 clipping treatments to randomly chosen plants. When the analysis of variance showed a 


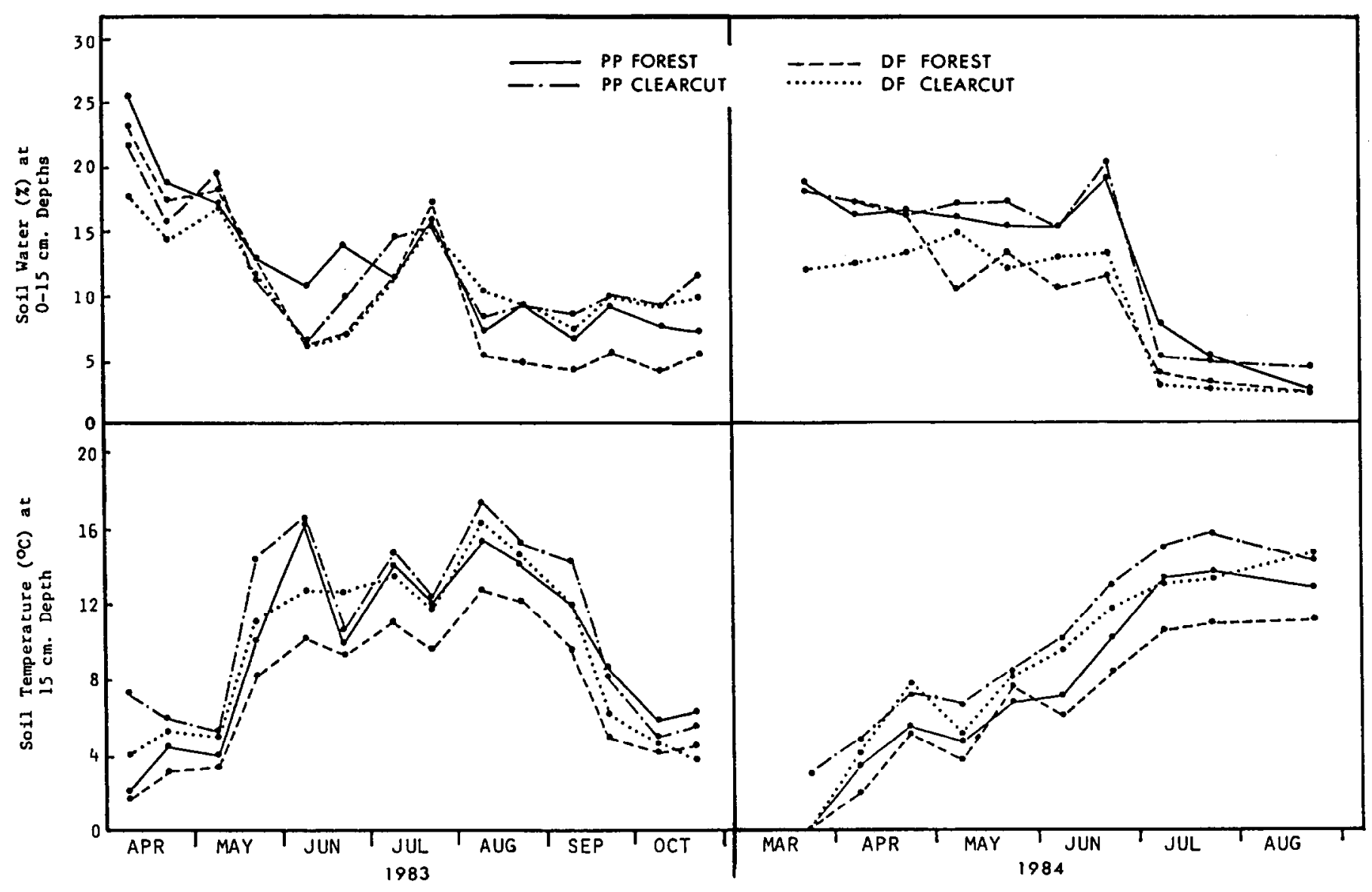

Fig. 2. Soil water (\%) and soil temperature (C) at $15 \mathrm{~cm}$ depth by site and date in 1983 and 1984.

significant treatment effect a Duncan's new multiple range test was used to test all possible comparisons between means (Steel and Torrie 1960). An alpha level of 0.05 was used to test for significant differences.

\section{Results and Discussion}

\section{Elk Sedge}

The seasonal reserve cycles of roots and root crowns of elk sedge showed little relationship to phenological development (Fig. 1). Root crown TNC levels were lowest in the spring and summer during the periods of leaf emergence, flowering, and seed production. Carbohydrate levels began to increase in late summer as soil water content decreased and soil temperature increased (Fig. 2). Kramer and Kozlowski (1960) reported that seasonal carbohydrate trends vary with different leaf habits; there is less fluctuation in the reserves of evergreen species than in deciduous species because of greater dependence on current photosynthesis than stored food for spring growth. This applies to elk sedge, which remains green over the winter months and retains the previous year's leaves until new leaves are formed the following spring. Late fall TNC levels in the root crowns averaged $96.7 \mathrm{mg} / \mathrm{g}$ while early spring levels averaged $60.9 \mathrm{mg} / \mathrm{g}$, indicating that significant amounts of TNC were used for winter respiration.

With all dates combined, TNC levels in elk sedge root crowns were greater in plants growing on the forested sites than on the adjacent clearcuts in 1983 (Table 1). In 1984, TNC levels in roots crowns were greater on the ponderosa pine forest than on the ponderosa pine clearcut; samples from the Douglas-fir forest showed only a trend higher levels than the Douglas-fir clearcut. When the 2 habitat types were compared, TNC was greater in plants on the ponderosa pine sites than the Douglas-fir sites in 1983. There was no difference in TNC levels of roots or root crowns between the 2 habitat types in 1984. Total nonstructural carbohydrate levels in plants are dependent upon the balance between growth, photosynthesis, and respiration and these factors are in turn affected by environmental conditions such as temperature and moisture. Blaser et al. (1966) found that soluble carbohydrates increased in orchardgrass (Dactylis glomerata L.) when low

Table 1. Total nonatructural carbohydrates (mg/g) averaged over all dates by site and species.

\begin{tabular}{lcccc}
\hline \hline & \multicolumn{4}{c}{ Site } \\
\cline { 2 - 5 } $\begin{array}{l}\text { Species and } \\
\text { plant part }\end{array}$ & $\begin{array}{l}\text { Ponderosa } \\
\text { pine forest }\end{array}$ & $\begin{array}{c}\text { Ponderosa } \\
\text { pine clearcut }\end{array}$ & $\begin{array}{c}\text { Douglas-fir } \\
\text { forest }\end{array}$ & $\begin{array}{c}\text { Douglas-fir } \\
\text { clearcut }\end{array}$ \\
\hline $\begin{array}{l}\text { Elk sedge } \\
\text { crowns (1983) }\end{array}$ & $75.4 \mathrm{~d}^{1}$ & $71.5 \mathrm{c}$ & $68.8 \mathrm{~b}$ & $61.8 \mathrm{a}$ \\
$\begin{array}{l}\text { Elk sedge } \\
\text { crowns (1984) }\end{array}$ & $77.1 \mathrm{~b}$ & $67.2 \mathrm{a}$ & $75.6 \mathrm{~b}$ & $70.3 \mathrm{ab}$ \\
$\begin{array}{l}\text { Elk sedge } \\
\text { roots (1983) }\end{array}$ & $111.4 \mathrm{~b}$ & $105.0 \mathrm{a}$ & $113.4 \mathrm{~b}$ & $105.5 \mathrm{a}$ \\
$\begin{array}{l}\text { Pinegrass } \\
\text { rhizomes (1984) }\end{array}$ & $71.1 \mathrm{ab}$ & $79.4 \mathrm{~b}$ & $69.2 \mathrm{a}$ & $90.4 \mathrm{C}$ \\
$\begin{array}{l}\text { Snowberry } \\
\text { crowns (1983) }\end{array}$ & $173.3 \mathrm{c}$ & $133.2 \mathrm{a}$ & $156.4 \mathrm{~b}$ & $149.9 \mathrm{~b}$ \\
$\begin{array}{l}\text { Snowberry } \\
\text { crowns (1984) }\end{array}$ & $174.8 \mathrm{~d}$ & $132.2 \mathrm{~b}$ & $156.3 \mathrm{c}$ & $112.5 \mathrm{a}$ \\
\hline
\end{tabular}

1 Means followed by a similar letter within each row are not significantly different at the 0.05 level of probability.

temperatures and water stress limited growth. Growth of orchardgrass was reduced relatively more by water stress than by photosynthesis and photosynthesis had a lower optimum temperature than growth. In 1983 and 1984 soil temperatures were lower on the forested sites than the adjacent clearcut sites. Seasonal averages of 


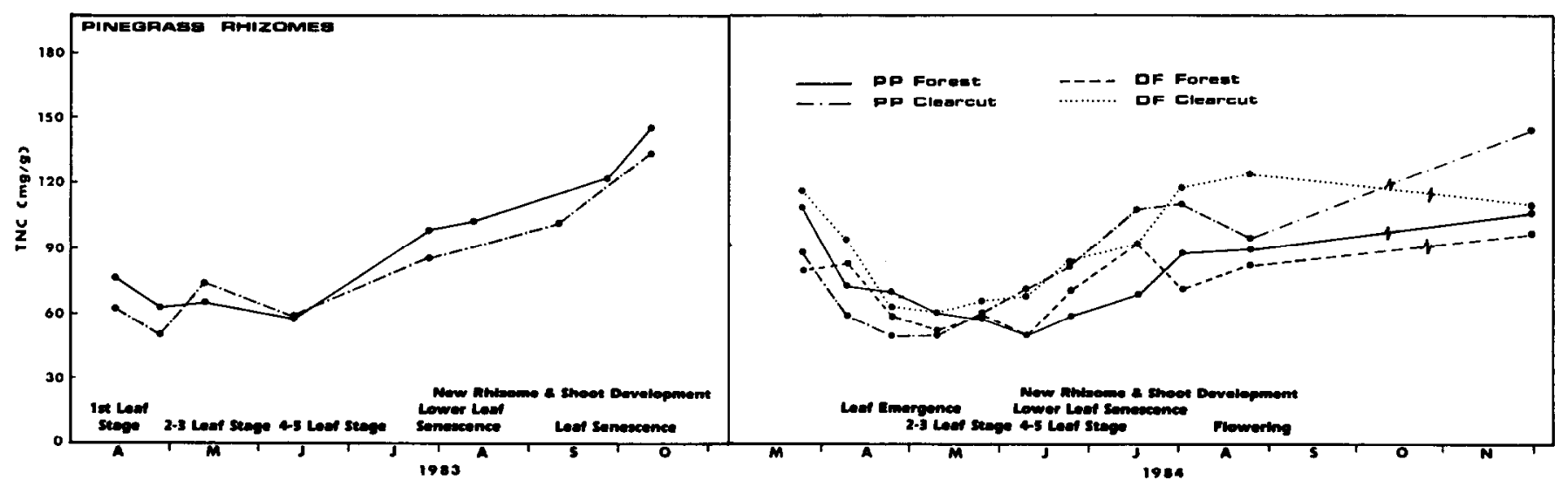

Fig. 3. The influence of site date on total nonstructural carbohydrates ( $\mathrm{mg} / \mathrm{g}$ ) in pinegrass rhizomes in 1983 and 1984 . Phenological stages of development are also included.

soil water content showed no difference among the 4 sites in 1983 or 1984; however, from August through October, 1983, soil water content was significantly less in the forested areas than in the clearcuts (Fig. 2). Vogel (1985) found less soil water in elk sedge rooting zones in a similar forest type compared to elk sedge in an adjacent clearcut. Elk sedge in the forest apparently responded to its environment with reduced growth and higher TNC levels when compared to an adjacent open environment.

\section{Pinegrass}

The seasonal TNC cycle of pinegrass can be described as a $\mathrm{U}$-shaped curve (Fig. 3). Growth initiation in the spring caused decreases in TNC content with the lowest levels occurring between the 3rd and 4th leaf stages. Rhizome TNC levels increased in June and July as plants produced new rhizomes and shoots. Descriptions of pinegrass (USDA 1937, Stubbendieck et al. 1982) state that reproduction is primarily by rhizomes except on open sites where flowering sometimes occurs. Only 4 plants were found to produce flowers in the 2 years of collections; thus, it could not be determined whether flowering had an effect on TNC levels.

Total nonstructural carbohydrate levels in pinegrass rhizomes averaged across all dates in 1984 were greater on the Douglas-fir clearcut than the Douglas-fir forest while the 2 ponderosa pine sites were not different (Table 1). Plants on the Douglas-fir clearcut had greater TNC than those on the ponderosa pine clearcut. Although no difference was found between TNClevels on the 2 forested sites, there appears to be a trend toward greater TNC in plants growing on the ponderosa pine forest.
Soil temperatures were significantly higher on the clearcut sites than the forest sites. Vogel (1985) found greater rooting zone soil water content and higher photosynthetic rates of pinegrass plants growing in a clearcut compared to an adjacent forest in a similar site. Therefore, we believe higher photosynthetic rates in pinegrass growing in the clearcut allowed for increased growth and TNC storage compared to pinegrass under the forest canopy.

\section{Snowberry}

Snowberry root crowns exhibited a V-shaped seasonal TNC curve with rapid drawdown during early spring growth followed by rapid replenishment (Fig. 4). In 1983 and 1984 the decrease in TNC was much greater in plants growing on the clearcut sites than the adjacent forested sites. The time at which TNC was at its lowest level varied not only by site but also by year. The lowest TNC levels ranged from 22 April on the ponderosa pine forest to 8 June on the Douglas-fir forest. A comparison between 1983 and 1984 showed that the TNC levels were from 3 weeks earlier to 10 days later depending on the site. Flowering of snowberry plants began in June when TNC levels were increasing. Approximately $75 \%$ of the plants on the clearcuts flowered compared to less than $20 \%$ of the forest plants. Full flower occurred in late July in 1983 and in late June in 1984. Fruit set and leaf senescence also occurred 1 month earlier in 1984 than in 1983 . July precipitation was above average in 1983 and below average in 1984. With all dates combined the TNC content of snowberry root crowns in 1983 was greater in the ponderosa pine forest than in the ponderosa pine clearcut, while there was no difference in TNC levels between the 2 Douglas-fir

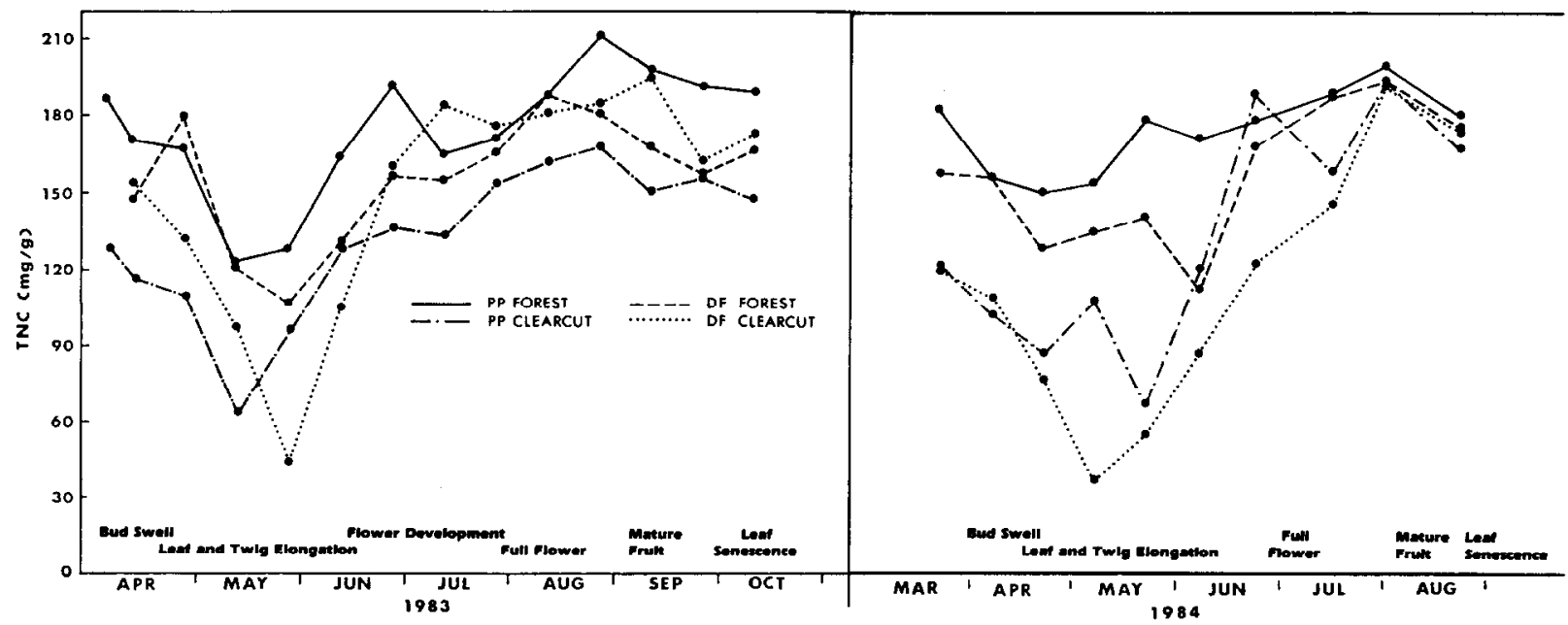

Fig. 4. The influence of site and date on total nonstructural carbohydrates $(\mathrm{mg} / \mathrm{g})$ in snowberry root crowns in 1983 and 1984 . Phenological stages of development are also included. 
sites (Table 1). In 1984, snowberry in both the ponderosa pine and Douglas-fir forested areas had higher TNC levels than snowberry in the adjacent clearcuts. Our results indicate that like elk sedge, growth of snowberry is reduced more by water stress than is photosynthesis. Therefore, snowberry growing under a forest canopy with higher water stress and lower soil temperatures have reduced growth and higher TNC levels.

\section{Clipping Treatments}

Elk Sedge

Clipping elk sedge plants on 24 May and 23 June caused significant reductions in TNC of root crowns (Table 2). Site differences in

Table 2. Total nonatructural carbohydrate (TNC) levels in elk sedge root crowns, elk sedze roots and pineprass rhizomes by clippins date, time following clipping and treatment averaged over all sites.

\begin{tabular}{|c|c|c|c|c|}
\hline \multicolumn{5}{|c|}{ Elk sedge root crowns } \\
\hline \multirow[b]{3}{*}{ Treatment } & & \multicolumn{2}{|c|}{ Clipping Date } & \\
\hline & \multicolumn{2}{|c|}{ May 24} & \multicolumn{2}{|c|}{ June 23} \\
\hline & 2 weeksl & 4 weeks & 2 weeks & 4 weeks \\
\hline $\begin{array}{r}\text { Control } \\
10 \mathrm{~cm} \\
5 \mathrm{~cm}\end{array}$ & $\begin{array}{l}70.8 \mathrm{~b}(y)^{2} \\
70.0 \mathrm{~b}(\mathrm{z}) \\
49.9 \mathrm{a}(\mathrm{y})\end{array}$ & $\begin{array}{l}75.8 \text { b (yz) } \\
58.1 \text { a (y) } \\
55.3 \text { a (y) }\end{array}$ & $\begin{array}{l}73.6 \mathrm{~b}(\mathrm{yz}) \\
53.5 \text { a (y) } \\
48.0 \mathrm{a}(\mathrm{y})\end{array}$ & $\begin{array}{l}79.7 \text { b (z) } \\
61.3 \text { a (yz) } \\
57.0 \text { a (y) }\end{array}$ \\
\hline
\end{tabular}

Elk sedge root

\begin{tabular}{|c|c|c|c|c|}
\hline \multirow[b]{3}{*}{ Treatment } & & \multicolumn{3}{|c|}{ Clipping Date } \\
\hline & \multicolumn{2}{|c|}{ May 24} & \multicolumn{2}{|c|}{ June 23} \\
\hline & 2 weeks & 4 weeks & 2 weeks & 4 weeks \\
\hline $\begin{array}{r}\text { Control } \\
10 \mathrm{~cm} \\
5 \mathrm{~cm}\end{array}$ & $\begin{array}{r}100.7 \mathrm{~b} \quad(\mathrm{x}) \\
97.5 \mathrm{ab}(\mathrm{y}) \\
89.5 \mathrm{a} \quad(\mathrm{y})\end{array}$ & $\begin{array}{r}111.5 \mathrm{~b}(\mathrm{y}) \\
111.2 \mathrm{~b}(\mathrm{z}) \\
96.2 \mathrm{a} \mathrm{(y)}\end{array}$ & $\begin{array}{r}108.3 \mathrm{~b}(y) \\
98.7 \mathrm{a}(\mathrm{y}) \\
95.6 \mathrm{a}(\mathrm{y})\end{array}$ & $\begin{array}{r}123.1 \mathrm{c}(\mathrm{z}) \\
108.6 \mathrm{~b}(\mathrm{z}) \\
99.1 \mathrm{a}(\mathrm{y})\end{array}$ \\
\hline
\end{tabular}

Pinegrass rhizomes

\begin{tabular}{|c|c|c|c|c|}
\hline \multirow[b]{3}{*}{ Treatment } & & \multicolumn{2}{|c|}{ Clipping Date } & \\
\hline & \multicolumn{2}{|c|}{ May 24} & \multicolumn{2}{|c|}{ June 23} \\
\hline & 2 weeks & 4 weeks & 2 weeks & 4 weeks \\
\hline $\begin{array}{r}\text { Control } \\
10 \mathrm{~cm} \\
5 \mathrm{~cm}\end{array}$ & $\begin{array}{l}59.2 \text { b (x) } \\
59.2 \text { b (x) } \\
45.9 \text { a (x) }\end{array}$ & $\begin{array}{l}73.2 \mathrm{a}(\mathrm{y}) \\
91.7 \mathrm{~b}(\mathrm{z}) \\
70.3 \mathrm{a}(\mathrm{y})\end{array}$ & $\begin{array}{l}90.9 \mathrm{~b}(\mathrm{z}) \\
77.2 \mathrm{a}(\mathrm{y}) \\
67.2 \mathrm{a}(\mathrm{y})\end{array}$ & $\begin{array}{l}97.1 \text { a (z) } \\
94.2 \text { a (z) } \\
84.9 \text { a (z) }\end{array}$ \\
\hline
\end{tabular}

'Time since clipping treatment.

${ }^{2}$ Means followed by a similar letter within each column or in parenthesis within each row are not significantly different at the 0.05 level of probability.

root crown TNC for clipped plants were similar to those of the nonclipped plants with the ponderosa pine forest plants having greater TNC levels than the ponderosa pine clearcut plants. There was no difference between the 2 Douglas-fir sites. Response to clipping was similar across all sites, resulting in no significant treatment by site interactions. Root TNC levels in the 10-cm clipping treatment showed no difference between the first clipping date and the second; however, TNC levels in the 5-cm clipping and control were higher after the second clipping date. This difference caused a significant clipping date by treatment interaction.

Because of the evergreen nature of elk sedge, no one phenological stage resulted in large changes in TNC content. However, clipping elk sedge twice before 30 June, during leaf emergence and flowering, caused TNC levels in both roots and root crowns to be reduced 4 weeks post-clipping in the 10- and 5-cm clipping treatments. Average plant regrowth 2-weeks following clipping on 24 May was 5 and $7 \mathrm{~cm}$ for the 5- and 10-cm clipping treatments, respectively. Four weeks following clipping on 24 May, average plant regrowth was 13 and $15 \mathrm{~cm}$ for the 5- and 10-cm clipping treatments, but only $2 \mathrm{~cm}$ regrowth was measured for clipped plants 4 weeks following the 23 June clipping.

\section{Pinegrass}

Total nonstructural carbohydrate levels in pinegrass rhizomes were affected by clipping on 24 May and 23 June (Table 2). Site differences were similar to those of the nonclipped plants; the 2 clearcut sites had higher TNC levels than the adjacent forest sites. The 5-cm clipping treatment had lower TNC levels than either the $10-\mathrm{cm}$ treatment or control on all sites except in the ponderosa pine clearcut where the $5-\mathrm{cm}$ and $10-\mathrm{cm}$ treatments were lower than the control. Although there were differences in plant phenology and average TNC levels, response to clipping treatments were similar across all sites resulting in no significant interactions.

Freyman (1970) clipped pinegrass plants to $15-\mathrm{cm}$ stubble heights over 12 different clipping treatments. He found that clipping pinegrass at 2-week intervals throughout the growing season or just before the summer dry period caused reductions in dry matter. Adequate regrowth occurred if clipping was done on or before 30 June, whereas there was no regrowth if clipping occurred after mid-July. Freyman (1970) suggested that the most desirable practice might be to graze pinegrass for 2 weeks in early June and again in August. Stout et al. (1980) found that yield, tiller height, and tiller number of pinegrass were reduced by clipping and that pinegrass was especially sensitive to herbage removal near the time of growth cessation in mid summer. Our study showed that clipping pinegrass plants to $10-\mathrm{cm}$ stubble heights twice before 30 June did not significantly affect rhizome TNC levels 4 weeks after treatment. Clipping to $5-\mathrm{cm}$ stubble heights twice before 30 June caused a reduction in TNC 2 weeks following treatment; however, TNC levels were replenished by 4 weeks. Regrowth for the 5-and 10-cm clipping treatments averaged 16 and $21 \mathrm{~cm}$, respectively, after the 24 May clipping but only 3 and $6 \mathrm{~cm}$ after the 23 May treatment. These data support the recommendations of Freyman (1970) and Stout et al. (1980) that pinegrass be grazed early before growth slows down prior to summer dormancy.

\section{Conclusions}

Total nonstructural carbohydrates in elk sedge, pinegrass, and snowberry were affected by forest habitat type, forest canopy cover, and date for our study sites. Significant site by date interactions occurred in these species because of differences in plant phenological development and should be considered in formulating grazing practices such as season-of-use and use intensity for forested sites. Each of the species also exhibited different types of TNC curves. Snowberry root crown TNC levels exhibited a Vshaped curve with a large decrease in TNC caused by spring growth followed by rapid replenishment of TNC levels. Because of the evergreen nature of elk sedge, no one phenological stage resulted in large differences in TNC content. However, our clipping study showed that elk sedge TNC levels were reduced when plants were clipped just after flowering and again after seed production in late May and late June, respectively. TNC levels were least affected when plants were clipped to a $10-\mathrm{cm}$ stubble height in late May and most affected when clipped to a 5-cm stubble height in both May and June.

Pinegrass rhizome TNC levels exhibited a V-shaped curve with reduced levels during spring growth and increased TNC levels after growth cessation in late summer. Clipping of pinegrass plants to a $5-\mathrm{cm}$ stubble height in both May and June or clipping to a $10-\mathrm{cm}$ stubble height in late June caused a reduction in TNC levels 2 weeks following treatment; however, after 4 weeks TNClevels were no different than controls. Clipping to a $10-\mathrm{cm}$ stubble height in late May did not cause a reduction in pinegrass rhizome TNC levels. These data support the recommendations of Freyman (1970) and Stout et al. (1980) that pinegrass be grazed early before growth slows down prior to summer dormancy; however, in western Montana we suggest that grazing of most moderate elevation Douglas-fir sites begin by mid-May rather than the first of June. 


\section{Literature Cited}

Blaser, R.E., R.H. Brown, and H.T. Bryant. 1966. The relationship between carbohydrate accumulation and growth of grasses under different microclimates. Int. Grassland Congress Proc. 10th p. 147-150. Sec. 1, Paper 14.

daSliveira, A.J., F.F. Teles, and J.W. Stull. 1978. A rapid technique for total nonstructural carbohydrate determination of plant tissue. J. Agr. Food Chem. 26:770-772.

Freyman, S. 1970. Effects of clipping on pinegrass. Can. J. Plant Sci. 50:736-739.

Hillel, D. 1971. Soil and water. Physical principles and processes. Acad. Press. New York.

Kramer, P.J., and T. Kozlowski. 1960. Physiology of trees. McGraw-Hill Book Co., New York.

Roseff, Scott J., and John M. Bernard. 1979. Seasonal changes in carbohydrate levels in tissues of Carex lacustris. Can. J. Bot. 57:2140-2144.

Smith, D., G.M. Paulsen, and C.A. Raguse. 1964. Extraction of total available carbohydrates from grass and legume tissue. Plant Phys. 39:960-962.

Steel, R.G.D., and J.H. Torrie. 1960. Principles and procedures of statistics. McGraw-Hill Book Co., New York.

Steele, Judith M., Raymond R. Ratlif, and Gary L. Ritenour. 1984. Seasonal variation in total nonstructural carbohydrate levels in Nebraska sedge. J. Range Manage. 37:465-467.

Steele, R.W. 1981. Weather data summary 1957-1980. Lubrecht Experimental Forest, Greenough, Montana. Misc. Paper 14. Montana Forest and Conserv. Exp. Sta., School of Forestry, Univ. of Montana, Missoula.
Stout, Darryl G., A. McLean, B. Brooke, and J. Hall. 1980. Influence of simulated grazing (clipping) on pinegrass growth. J. Range Manage. 33:286-291.

Stout, Darryl G., Michio Suzukd, and B. Brooke. 1983. Nonstructural carbohydrate and crude protein in pinegrass storage tissues. J. Range Manage. 36:440-443.

Stubbendieck, J., S.L. Hatch, and K.J. Kjar. 1982. North American range plants. Univ. of Nebraska Press, Lincoln.

Trlica, M.J. 1977. Distribution and utilization of carbohydrate reserves in range plants, p. 73-96. In: R.E. Sosebee (ed.), Rangeland Plant Physiology. Soc. Range Manage., Denver, Colo.

USDA Foreat Service. 1937. Range plant handbook. U.S. Government Printing Office, Washington, D.C.

Vogel, Sheryl A. 1985. Influence of canopy cover and simulated grazing on water relations, stomatal conductance and photosynthesis of pinegrass and elk sedge. M.S. Thesis, Univ. of Montana, Missoula.

White, Larry M. 1973. Carbohydrate reserves of grasses: A review. J. Range Manage. 26:13-17.

Willard, E.E., D.J. Bedunah, and W. Hann. 1983. Forage and livestock in western Montana. p. 187-208. In: J. O'Loughlin and R.D. Pfister (ed), Management of second-growth forests: The state of knowledge and research needs. Montana Forest and Conservation Experiment Station, University of Montana, Missoula.

\section{Tools for Research from SRM}

Range Research:

Basic Problems and Techniques

Edited by C. Wayne Cook and

James Stubbendieck

This major revision of an earlier publication by NAS presents steps in research planning, evaluation of results, and methods and procedures in range research including sampling techniques and experimental design. (336 pages, hard cover, \$25)

\section{5-Year Index}

to the Journal of Range Management

(Vol. 1 through 35, 1948-1982)

\section{Edited by Elbert H. Reid}

The index contains a chronological list of all articles published in the first 35 years of the journal as well as an alphabetical listing of keywords, taxons, and authors of all articles.

(100 pages, perfect bound and sewed, $\$ 10$ )

Available from the Society for Range Management, 1839 York Street, Denver, Colorado 80206. Telephone (303) 355-7070. 